\title{
Feeding behaviour of wethers fed ad libitum or limited-fed with hay of natural meadows
}

\author{
A Kirilov \\ Forage Institute, 5800 Pleven, Bulgaria
}

Feeding behaviour of ruminants is closely connected with quality indices of forage. The objective of this study is to compare feeding behaviour of wethers fed either ad libitum or limited-fed with meadow hay.

Six wethers, 4-year-old, live weight $73.1 \pm 2.0$ $\mathrm{kg}$, of the Danube fine wool breed, were consecu-tively fed ad libitum (10\% refusals) FAL, and limited-fed ( $60 \%$ of forage intake ad libitum) LF. Hay of natural meadow containing $8.4 \%$ crude protein, $31.5 \%$ crude fibre, $2.2 \%$ crude fat and $9.9 \%$ ash of dry matter (DM), was given two times per day - at 8 am and at $4: 30 \mathrm{pm}$. Preliminary period was 3 weeks in FAL and 2 weeks in LF. The feeding behaviour was observed during 48 hours at the end of every 8-day experimental period to determine forage digestibility. The feeding parameters were defined according to Dulphy (1971, Ann Zootech, 20, 477-486) and Dulphy and Demarquilly (1974, Ann Zootech, 23, 193-212). The index of forage fibrousness was calculated according to Balch (1971, Br J Nutr, 26, 383-392).

DM intake was 1568 in FAL and $974 \mathrm{~g} /$ head/day in LF. FAL animals selected and ate the forage calmly and slowly. They spent more time eating $1 \mathrm{~kg}$ hay DM, compared to LF $-174.3 \mathrm{vs}$ $79.9 \mathrm{~min} / \mathrm{kg}$ DM intake, i.e. intake rate was greater in LF than in FAL : 12.6 vs $6.0 \mathrm{~g} / \mathrm{min}$.
Meal number was 8 in FAL and only 2 in LF. The forage ration in LF was eaten entirely during the main meal and immediately after forage distribution. There was no significant difference in the length of meal between the two modes of feeding, but the time spent eating the main meal was much greater in FAL - $89.7 \mathrm{~min}$, compared to LF - $38.8 \mathrm{~min}$.

The differences between rumination parameters were opposite to those of forage intake. Unitary ruminating time was longer in LF (444.1 $\mathrm{min} / \mathrm{kg}$ DM intake) than in FAL (346.8 $\mathrm{min} / \mathrm{kg} \mathrm{DM}$ intake), i.e. ruminating rate was higher in FAL ( $3 \mathrm{~g} / \mathrm{min})$, compared to LF $(2.3 \mathrm{~g} / \mathrm{min})$. These facts are probably related to commonly observed lower digestibility of forages fed ad libitum. There was no significant difference in the number of ruminating periods, but in FAL the length of a ruminating period was greater compared to LF : 36.4 vs $27.8 \mathrm{~min}$. There was no difference in chewing rate, and the index of forage fibrousness was the same at the two modes of hay feeding.

In conclusion, wethers fed ad libitum with meadow hay spend more time eating and less time ruminating $1 \mathrm{~kg} \mathrm{DM}$, compared to limited feeding, but the total time of eating and ruminating $1 \mathrm{~kg} \mathrm{DM}$ was the same for the two modes of feeding.

\begin{tabular}{lcc}
\hline Parameters & ad libitum & limited-fed \\
\hline DM digestibility (\%) & $55.1^{\mathrm{a}}$ & $60.9^{\mathrm{b}}$ \\
DM intake (g/head/day) & 1568 & 974 \\
Forage intake during the main meal (g) & 574 & 487 \\
Time spent eating (min) & $268.6^{\mathrm{a}}$ & $77.8^{\mathrm{b}}$ \\
Unitary eating time (min/kg DM intake) & $174.3^{\mathrm{a}}$ & $79.9^{\mathrm{b}}$ \\
Time spent ruminating (min) & $543.0^{\mathrm{a}}$ & $432.6^{\mathrm{b}}$ \\
Unitary ruminating time (min/kg DM intake) & $346.8^{\mathrm{a}}$ & $444.1^{\mathrm{b}}$ \\
Time spent chewing (min) & $822.4^{\mathrm{a}}$ & $510.4^{\mathrm{b}}$ \\
Intake rate (g/min) & $6.0^{\mathrm{a}}$ & $12.6^{\mathrm{b}}$ \\
Ruminating rate (g/min) & $3.0^{\mathrm{a}}$ & $2.3^{\mathrm{b}}$ \\
Chewing rate (g/min) & $2.0^{\mathrm{a}}$ & $1.9^{\mathrm{a}}$ \\
Number of meals & $8.0^{\mathrm{a}}$ & $2.0^{\mathrm{b}}$ \\
Time spent eating 1 meal (min) & $35.3^{\mathrm{a}}$ & $38.8^{\mathrm{a}}$ \\
Time spent eating the main meal (min) & $89.7^{\mathrm{a}}$ & $38.8^{\mathrm{b}}$ \\
Number of ruminating periods & $15.4^{\mathrm{a}}$ & $15.8^{\mathrm{a}}$ \\
Length of 1 ruminating period (min) & $36.4^{\mathrm{a}}$ & $27.8^{\mathrm{b}}$ \\
Fibrousness index (min) & $521^{\mathrm{a}}$ & $524^{\mathrm{a}}$ \\
\hline Numbers
\end{tabular}

Numbers within a row followed by the same letter are not significantly different at the $5 \%$ level. 